\title{
Values Conveyed through Distance Education in Geometry Courses during COVID-19
}

\section{COVID-19 Sürecinde Uzaktan Eğitim ile Geometri Derslerinde Aktarılan Değerler}

\author{
Yüksel DEDE*
}

\author{
Veysel AKÇAKIN** (D)
}

\author{
Gürcan KAYA*** (D)
}

Received: 21 February 2021

Research Article

Accepted: 27 April 2021

ABSTRACT: Due to the COVID-19 pandemic, countries have had to adapt their usual teaching environment and processes to distance education. The purpose of this study was to investigate the Grade 9 geometry course contents shared on the Education Information Network (EBA) platform in terms of mathematics values (mathematical values and mathematics educational values). This study was a qualitative research based on document review. Data were collected from the Grade 9 geometry course contents in the EBA affiliated to the Turkish Ministry of National Education (MoNE) and analysed using semantic content analysis. The results showed that the mathematical values such as objectism, openness, rationalism, and the mathematics educational values such as formalistic view, inquiry, instrumental understanding, facts $\&$ theories are often emphasised in geometry courses through distance education. The results of the study were also compared with the results of studies of mathematics courses through face-to-face education in the related literature and some suggestions were also made for further studies in this context.

Keywords: COVID-19, distance education, grade 9 geometry course contents on the EBA, values, mathematical values, mathematics educational values.

ÖZ: COVID-19 salgını nedeniyle, ülkeler alışılagelen öğretim ortam ve süreçlerini uzaktan eğitimle değiştirmek zorunda kalmıştır. Bu bağlamda bu çalışmanın amacı, Eğitim Bilişim Ağı [EBA] platformunda paylaşılan dokuzuncu sınıf geometri ders içeriklerini matematik değerleri (matematiksel değerler ve matematik eğitimsel değerleri) açısından incelemektir. Bu anlamda bu çalışma, doküman incelemesine dayalı nitel bir araştırmadır. Veriler, Milli Eğitim Bakanlığı [MEB]- EBA platformundaki 9. sınıf geometri ders içeriklerinden elde edilmiş ve anlamsal içerik analizi kullanılarak analiz edilmiştir. Sonuçlar, nesnellik, açıklık, rasyonellik gibi matematiksel değerler ile formalistik bakış, sorgulama, araçsal anlama, olgular ve teoriler gibi matematik eğitimi değerlerinin uzaktan eğitim ile yapılan geometri derslerinde sıklıkla vurgulandığını ortaya koymuştur. Araştırmanın sonuçları, ilgili literatürdeki yüz yüze eğitim ile yapılan matematik derslerine yönelik çalışmaların sonuçlarıyla da karşılaştırılmış ve bu bağlamda ileri çalışmalar için de bazı önerilerde bulunulmuştur.

Anahtar kelimeler: COVID-19, uzaktan eğitim, 9. sınıf geometri dersi EBA içerikleri, değerler, matematiksel değerler, matematik eğitimi değerleri.

\footnotetext{
* Corresponding Author: Prof. Dr., Gazi University, Gazi Faculty of Education, Ankara, Turkey, ydede@ gazi.edu.tr, https://orcid.org/0000-0001-7634-4908

** Asst. Prof. Dr., Uşak University, Faculty of Education, Uşak, Turkey, veyselakcakin@usak.edu.tr, https://orcid.org/0000-0002-7705-0722

*** Asst. Prof. Dr., Afyon Kocatepe University, Faculty of Education, Afyonkarahisar, Turkey, gurcankaya@aku.edu.tr, https://orcid.org/0000-0001-8380-1708
}

\section{Citation Information}

Dede, Y., Akçakın, V., \& Kaya, G. (2021). Values conveyed through distance education in geometry courses during COVID-19. Kuramsal Eğitimbilim Dergisi [Journal of Theoretical Educational Science], 14(3), 432-448. 
The whole world lives in uncertain times in 2020 due to COVID-19 pandemic, and in this process, public health is at the forefront of our minds. Most schools all over the world have been interrupted in the 2019-2020 school year with the ways we have never seen before. These crises have naturally led to disruptions in the relationships among students and between students and teachers in the learning and teaching of mathematics. Although no one has an insight into what education will be like in the coming processes and times, we should plan well for them to consider how to meet the needs of students in the best way. For this purpose, the National Council of Supervisors of Mathematics (NCSM) and the National Council of Teachers of Mathematics (NCTM) have prepared a joint report for COVID-19 to make informed decisions and take steps for the future. The document is organised around three major areas for equitable access to high-quality mathematics teaching and learning in the pandemic situation: structural considerations, teaching practices and, advocacy. Thus, it targets to build and sustain a positive identity and disposition towards mathematics for all teachers and students (NCSM \& NCTM, 2020). Aims and tendencies of the three major areas indicate that many things will differ in the learning and teaching of mathematics during the COVID19. For example, in this process, distance education can be considered compulsory because of the shutdown of schools to prevent the spread of COVID-19 and students and teachers' dispositions such as attitudes, beliefs, and values towards mathematics can differ.

\section{Education and COVID-19}

Educators have become aware of the two important goals of education since the Confucius and Socrates periods. These goals are to convey the meaning and importance of the past and prepare students for future challenges. Because the things that students need to learn change over time, naturally educational environments, conditions, and curriculums should not be static. They should be updated constantly according to the requirements of the century. In many countries around the world in recent years, they have already been significantly revised because today's students live in a digital world and use the possibilities of this world in different ways (e.g., distance education, access to online resources). For example, nineteenth-century students had no choice but to go to school. Nowadays, scientific knowledge evolves very quickly, but at the same time, social problems become very complex. Radical changes are made in the learning environments and processes to respond to them (Organisation for Economic Co-operation and Development [OECD], 2019c). As mentioned before, COVID-19 has often caused an unpredictable rapid change in the learning and teaching environments and processes. Formal education has been suspended in many countries due to COVID 19, which now affects the globe, and it has been declared a pandemic disease by the World Health Organization (WHO). As a result, many countries (e.g., Turkey, China) decided to switch to distance education at all education levels.

\section{Distance Education and Mathematics Teaching}

In recent years, technological innovation has become widespread. These developments have deeply influenced many things, including the emergence and rise of schools that teach fully distance education, as well as how to teach in traditional face-toface schools, how curricula will be, and what the nature and level of the courses will be 
(Juan et al., 2012). However, it is seen that distance education has been defined in many ways. For example, Taylor (2015) defined distance education as a formal education process in which most of the instruction in a course (interaction among students, between students and teachers) occurs when students and teachers are not in the same place. Moore (2019) also saw distance education as "the methodology of structuring courses and managing dialogue between teacher and learner to bridge that gap through communications technology." (p. 34). As these definitions indicate, distance education generally refers to a situation where students and teachers are in different environments and communication with technology devices is established. Distance education courses can also be synchronous or asynchronous and can be done in many ways: the use of the internet, broadband lines, cable, microwave, wireless communication devices, and audio conferencing etc. (Taylor, 2015).

On the other hand, like technology, mathematics is also not value-free; it promotes certain types of behaviour (see Bishop, 1988). Also, throughout history, economic, technological, and scientific needs have been the priority in the adventure of development of mathematics. Mathematics is, therefore, not a static part of knowledge and a complete process. In all cultures and at all times, mathematics can and will evolve and continue to carry cultural values and pieces within (Haylock \& Thangata, 2007). Curricula, teachers, and institutions should address the perception and emotions provoked by this discipline (Barbera, 2012). In addition, cultural differences can lead to the teaching of the same mathematical content with different approaches (Seah, 2003), and therefore teaching mathematics might vary in different cultures and educational systems (Atweh \& Seah, 2008).

Meanwhile, new developments in educational technology are changing the way of teaching (Juan et al., 2012). Considering these innovations, the teaching of mathematics also introduces different approaches, such as distance education, as well as traditional face-to-face instruction. With these new approaches, new values and beliefs will be conveyed to mathematics teaching environments and processes consciously or unconsciously.

\section{Values and Mathematics Teaching}

OECD Learning Compass 2030 has suggested a very conceptual and useful framework for future teaching. The framework defined four essential competencies: knowledge, skills, attitude, and values, which are developed interdependently (OECD, 2019b). This current study focused on values only from these competencies, considering the new values that accompany evolving teaching approaches adopted during the pandemic.

Values are effective in the individuals to continue and commit to any action they choose in the learning and teaching of mathematics (Seah \& Andersson, 2015). For example, if someone values creativity, s/he might want to pursue a career in the art field. A person who greatly values public service can join the society to serve others (Diestler, 2012). Cognitive competencies and emotional dispositions of a student (i.e., as a conative variable) are aligned with learning in any socio-cultural learning environment given (Seah \& Andersson, 2015). In this context, Lim and Ernest (1997) classified the values in mathematics education: epistemological values, social and cultural values, and personal 
values. Bishop (1988) also categorised three types of values conveyed in the mathematics education: general educational, mathematical, and mathematics educational values. General educational values relate to the values of the general society, such as obedience, honesty, integrity. Mathematical values are the values produced by mathematicians who grow up in different cultures and reflect the nature of mathematical knowledge (Bishop et al., 1999). At this point, Bishop (1988) used four-component dimensions of culture proposed by White (1959/2007). These: ideological component, sentimental component, sociological component, and finally technological component. Bishop (1988) also interpreted the four components in terms of mathematical thinking and values and evaluated mathematics as containing symbols, expressing that cultural growth could be through mathematics and other technologies (Seah, 2008). In this context, Bishop (1988) considered the technology component an umbrella of three complementary mathematical value pairs.

Additionally, mathematics educational values are the values that reflect the pedagogical aspect of school mathematics (Seah et al., 2017), and they refer to the extent to which the trends of norms and practices related to the teaching or learning of mathematics are valued (Seah, 2011). Both mathematical and mathematics educational values have the potential to affect the quality of a student's learning of mathematics. General educational values do not directly affect students' mathematics performance (Seah et al., 2017).

\section{Distance Education and Mathematics Values in Turkey}

Here, the distance education process in Turkey (during the COVID-19) and the mathematics values (mathematical values and mathematics educational values) of mathematics teachers and students in Turkey are briefly summarised.

\section{Distance Education during the COVID-19 in Turkey}

Formal education was paused for a week in schools in Turkey due to the COVID19 pandemic on March 16, 2020, and distance education started on March 23, 2020. Considering that many students do not have access to online education (see Bakker \& Wagner, 2020), distance education has started for more than 18 million students at primary, secondary, and high school level through three new state television channels (the Turkish Radio and Television Institution (TRT) - Education Information Network [in Turkish EBA] TV primary school, TRT EBA TV secondary school, and TRT EBA TV high school), and the EBA, whose network capacity has been increased in this one-week period by MEB. As of March 23, 2020, it has been decided to continue the distance education broadcasts, which started on the televisions of the TRT, until at least April 30, 2020 with the suggestion of the COVID-19 Scientific Committee formed by the Ministry of Health of Turkey. Later, MEB decided to continue this distance education process until June 1,2020. Then it decided to end this period with distance education completely (until June 19, 2020). In addition, if everything went normal, MEB announced that schools would begin face-to-face education on August 31, 2020. As of November 2020, schools switched to hybrid models for various education levels.

In this context, on television channels that are opened separately for primary, secondary, and high school levels, 20-25 minutes of course rebroadcast at all grade levels (K-12) continue until evening hours. EBA, one of the largest digital education platforms 
in the world that provides online service, offers students rich contents and over 20 thousand interactive content and live broadcast. EBA is a social educational electronic content network established by the MEB. Contents and course materials needed by teachers and students, which will help education, are provided online to all students and teachers in Turkey via the internet within the scope of "Movement of Enhancing Opportunities and Improving Technology" Project (FATIH), which was launched in 2010. The FATİH project aims to use information technology tools effectively in courses to address more sense organs in the learning-teaching process to achieve equality of opportunity in education and improve technology in schools in Turkey (MEB, n.d.). EBA was established within the scope of FATİH project.

EBA enables the integration of technology into education by using information technologies and provides reliable content suitable for class levels. In addition, education firms, teachers and students can upload their content to the EBA platform. Furthermore, parents can see the quality of the education by following it on EBA. Consequently, MEB recommends that students follow their courses on TRT EBA TV; use EBA for review, missing topics and questions, and teachers help their students remotely through different communication tools (internet, mobile phone, etc.) in this process. Three major Global System for Mobile Communications (GSM) operators in Turkey also provided free internet service for all students, and their parents up to 6-8 gigabyte (GB) for access to the EBA, as all courses are available online. Thus, Accessibility and Equality principles were tried to be provided among the basic principles of the FATIH Project.

\section{Mathematics Values in High Schools in Turkey}

The MEB is responsible for compulsory education in Turkey, and compulsory education in Turkey is free and lasts for 12 years. The education system of Turkey is based on an examination-oriented education (Dede, 2019), and students continue their education careers based on the results of high-stakes examinations with multiple choice conducted at the end of middle and high schools. This naturally causes a lot of pressure on the students. In the recent Programme for International Student Assessment [PISA] 2018 , the ratio of the achievement level of the lower level of students in Turkey decreased, the ratio of the achievement level of higher-level students increased. In addition, it is at the top of the trend of Turkish students' internal motivations and mathematics values (OECD, 2019d). Some research studies have been conducted to determine what students and teachers' value in the context of mathematics courses. In a recent study (Dede \& Barkatsas, 2019), 511 high school grade ninth students (14-15 years old) in Turkey responded to survey items, which asked them what they found important in their mathematics learning. The six most valued attributes of mathematics learning were found: relevance $(\mathrm{C} 1)$, practice $(\mathrm{C} 2)$, information and communications technology (ICT) (C3), feedback (C4), learning approach (C5), and consolidating (C6). Findings of this study showed that ninth-grade students value relevance in their mathematics learning highly. Also, the descending order of the value mean scores for grade ninth were practiceconsolidating-relevance-learning approach-feedback-ICT and practice-feedbacklearning approach-consolidating-relevance-ICT, respectively. In addition, the results pointed out that ninth-grade students see practice as the most important value for their mathematics learning within six values. 
With high stake examination in Turkey, students are measured with mathematical skills and the ability to use time as efficiently as possible. For this reason, the students need to solve as many mathematics questions and problems as possible to pass these exams. Conversely, ICT value was valued least by grade ninth students when compared to the other five values. This result shows that students still cannot give up traditional teaching methods, although ICT has been gradually incorporated into the day-to-day mathematics teaching and learning activities in educational settings in Turkey. Similarly, the results of a recent qualitative study of Dede (2019) with ninth-grade students were also partially like those of Dede and Barkatsas (2019). Accordingly, the students' mathematics values are gathered in four main categories: practice, relevance, rationalism, and fun. In this study, practice value was determined to be among the values that students in Turkey give importance.

\section{Purpose and Importance of the Study}

The purpose of the current study is to examine the Grade 9 mathematics course contents shared on the EBA platform in terms of mathematics values. Due to the COVID19 pandemic, countries have had to change their usual teaching environment and processes (especially formal education) with distance education. Moreover, in this process, the traditional boundaries in practices have suddenly changed (Bakker \& Wagner, 2020). All cultures and, therefore, education systems are also affected by this sudden and rapid change. This can also lead to a change in the values that societies, cultures and therefore education systems conveyed. This is because no education system is neutral, and every state and society want to convey their values to their students for their own future (Powe, 1993). Therefore, it is important to know the values conveyed in teaching processes for a conscious values education (Hill, 1991).

Moreover, the values conveyed in the teaching processes of mathematics affect the quality of students' mathematics learning experience (Seah et al., 2017). In this context, values are conveyed to students in formal education processes and environments, as well as in distance education environments or via television consciously or unconsciously. In this sense, when the relevant literature is examined, it is determined that there are no studies examining the values conveyed to students in distance education environments, although there are some studies examining the mathematics values of teachers (e.g., Aktaş \& Argün, 2018; Dede, 2015; Lin et al., 2006) and students (e.g., Dede \& Barkatsas, 2019; Zhang et al., 2016) at the formal education levels (especially in the Grade 9) have been conducted. In this context, it will be possible to compare the results of the current study within the possible similarities and differences of the aforementioned studies, which reveal the mathematics values conveyed to students through formal education in terms of socio-cultural and conative aspects. In addition, Bishop (1988) evaluated the technology component as an umbrella of the mathematical values. Therefore, we can consider distance education and its applications under the technology component here. This can enable values that are not possible to be determined in traditional face-to-face education.

Moreover, as mentioned before, the importance of determining the values conveyed in the EBA mathematics course contents with distance education increases, even more, considering that the ICT value is the value that the middle and high school 
students in Turkey value least. In this sense, the current study is thought to be a significant contribution to the literature. Additionally, by comparing the results of the present study with the results of previous studies conducted with formal education and exemplified above, the role and effects of this sudden and rapid change in mathematics teaching environments on the conveyed mathematical values in teaching processes can be clearly seen. Nowadays, when mathematics teaching is evolving rapidly and suddenly, it is thought that the knowledge and results regarding the possible evolution of the values conveyed in today's teaching processes can also guide all education stakeholders (policy and curriculum makers, teachers, etc.) in order to provide a more conscious education of values.

On the other hand, the content of the courses developed on the EBA platform will be examined affectively and socio-culturally. Thus, it is planned to offer some suggestions for the development of teaching processes of mathematics, not only in terms of cognition but also in terms of affective and socio-cultural aspects. It is also thought that the content of EBA mathematics courses to be developed in the context of these possible suggestions can be an important and rich resource in terms of being compatible with 21 st-century skills and the OECD Learning Compass 2030 competencies. For these purposes, the problem statement of this study is as follows:

What are the mathematics values conveyed through distance education in ninthgrade geometry courses with EBA videos in Turkey during the COVID-19 pandemic?

\section{Method}

\section{Research Design}

In the current study, course videos were used as data source. First of all, the course videos were transcribed so that documents to be used within the scope of the study were created. In this respect, the current study is a qualitative research conducted through document review.

\section{Data Collection}

Data were collected from the Grade 9 geometry course contents that exist in the EBA affiliated to the MEB between March 23, 2020, and April 30, 2020 (see Table 1). All Grade 9 geometry course contents at the EBA were taught by a male mathematics teacher with more than 20 years of seniority. Support from experts from the MEB and the universities in Turkey was also received to prepare and present the course contents.

Table 1

Grade 9 Geometry Course Contents

\begin{tabular}{ccc}
\hline & Time & \multicolumn{1}{c}{ Lesson } \\
\hline $9-1$ & $20: 00$ & Lesson 1: Angle-Side Relationships in a Triangle-1 \\
$9-2$ & $23: 51$ & Lesson 2: Angle-Side Relationships in a Triangle-2 \\
$9-3$ & $21: 06$ & Lesson 3: Angle-Side Relationships in a Triangle-3 \\
$9-4$ & $25: 09$ & Lesson 4: Congruent Triangles- 1
\end{tabular}




\begin{tabular}{lll}
$9-5$ & $25: 15$ & Lesson 5: Congruent Triangles- 2 \\
$9-6$ & $27: 39$ & Lesson 6: Similarity in Triangles -1 \\
$9-7$ & $24: 24$ & Lesson 7: Similarity in Triangles -2 \\
$9-8$ & $23: 05$ & Lesson 8: Similarity in Triangle -3 \\
$9-9$ & $23: 42$ & Lesson 9: Auxiliary Elements in Triangle -1 \\
$9-10$ & $28: 25$ & Lesson 10: Auxiliary Elements in the Triangle-2 \\
$9-11$ & $22: 29$ & Lesson 11: Auxiliary Elements in Triangle-3 \\
$9-12$ & $31: 34$ & Lesson 12: Auxiliary Elements in Triangle-4 \\
$9-13$ & $31: 44$ & Lesson 13: Pythagorean Theorem \\
$9-14$ & $29: 27$ & Lesson 14: Euclidean Theorem \\
& 357 min $50 \mathrm{sec}$ & 25.755 words \\
\hline
\end{tabular}

After the contents to be analysed were determined and transcribed, repeated review, examination and interpretation were made to obtain the meaning and empirical information of the values in the EBA contents. A sample geometry course content for Grade 9 is presented in Table 2.

\section{Table 2}

\section{Sample Course Content Transcripts for Grade 9 (First 2 Minutes)}

Subject: Lesson 1, The Angle-Side Relationship

Friends, our subject is to show the angle-side relationships in the triangle.

We can first explain the relationship between angle and side with a relation like this.

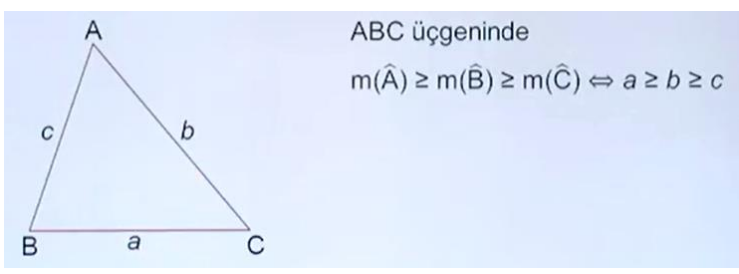

A triangle has a longer side across a big angle and a small side across a small angle. If the angle measures are equal, the opposite sides are equal.

So, the side gets longer as the angle gets bigger, and the angle gets bigger as the side gets longer. But we are not saying that there is a proportion. We are just trying to say that if we reduce the measure of the angle, we reduce the length of side, if we reduce the side, we reduce the angle. If the measures of the angles are equal, we say that the sides are equal.

In a triangle $\mathrm{ABC}$, if the angle measure $\mathrm{A}$ is greater than or equal to $\mathrm{B}$, the angle measure $\mathrm{B}$ is greater than or equal to $\mathrm{C}$, then order of the side lengths become as follows: length of side a is greater than or equal to side $\mathrm{b}$, length of side $\mathrm{b}$ is greater than or equal to side $\mathrm{c}$ and vice versa. $(m(\hat{A}) \geq m(\hat{B}) \geq m(\hat{C}) \Leftrightarrow a \geq b \geq c)$

The ordering between the edges will give the ordering between the angles. Let's not try to establish any proportion; please just go with the logic of greater than or smaller. Friends, our next feature is these.

\section{Data Analysis}

Semantic content analysis, one of the qualitative data analysis methods, was used to analyse the videos. Semantic content analysis is the process of creating subcategories 
to detect themes in a text or phenomenon (Tavşanc1l \& Aslan, 2001). In this sense, the EBA contents reviewed were analysed based on the values and value signals that emerged in the literature (for example, Bishop, 1988; Dede, 2012, 2015, 2019; Dede \& Barkatsas, 2019; Lim \& Ernest, 1997; Seah, 1999, 2011). As mentioned above, the general educational values have not been analysed in the current study since they do not directly affect students' mathematics achievement (Seah et al., 2017). In the present study, in the EBA contents, mathematics values (mathematical values and mathematics educational values) are chosen as topic areas. In this sense, words, sentences or paragraphs, and contents can be considered as an analysis unit (Yıldırım \& Şimşek, 2008). In this study, mathematics values that exist in the EBA content are examined in the terms of sentence to prevent the probability of missing the meaning of the sentence while analysing words and paragraphs (Yıldırım \& Şimşek, 2008) by considering indicators of the aforementioned values. And the analyses continued until theoretical saturation was reached (Arber, 1993). A word that points to a value can also refer to both mathematics, mathematics education, and general educational value (see Seah \& Bishop, 2000). Some examples of how Grade 9 geometry courses are analysed in terms of mathematics values are presented in Table 3 .

\section{Trustworthiness of the Study}

"Theoretical triangulation" (Cohen et al., 2018, p. 266) was applied in this study to reveal the values by comparing the value signals/codes in the literature. Peer review was used in this study in order to ensure reliability (Lincoln \& Guba, 1985). Values, which authors coded, were also coded separately by two experts in mathematics education. In this context, $10 \%$ of the EBA contents for each grade level examined were given to these two experts (MacNealy, 1999), and they were asked to separate these contents independently according to the values and value signals. In the light of expert feedbacks, values were updated. At the end of this process, Kappa values calculated between researchers and experts were calculated as .86 and .91, respectively. These values indicate a significant agreement in coding between researchers and experts (see Landis \& Koch, 1977).

\section{Ethical Procedures}

In this study, archived course contents and videos on the EBA platform affiliated to the Ministry of Education were used. Therefore, no data was collected from any participant. Since no data was collected from any participant, it was not deemed necessary to apply to ethical committee.

\section{Results}

In this section, mathematical and mathematics educational values of 14 course videos were examined. Sample analysis in terms of mathematics values of mathematics course contents is given in Table 3. 
Table 3

Sample Analysis of Geometry Courses in terms of Mathematics Values

\begin{tabular}{lll}
\hline \multicolumn{1}{c}{ Statements } & Mathematics Values & \multicolumn{1}{c}{ Value Signal } \\
\hline $\begin{array}{l}\text { Friends, our subject is to show } \\
\text { angle-side relationships in the triangle }\end{array}$ & Openness & $\begin{array}{l}\text { Interpersonal distance- use } \\
\text { of pronoun 'we' and related } \\
\text { forms. } \\
\text { Interpersonal distance- use } \\
\text { of 'student(s)' etc. }\end{array}$ \\
\hline $\begin{array}{l}\text { A triangle has a longer side across a big angle } \\
\text { and a small side across a small angle. If the } \\
\text { measures of the angles are equal, then the } \\
\text { opposite sides are equal. }\end{array}$ & $\begin{array}{l}\text { Formalistic view of } \\
\text { mathematics learning } \\
\text { vocabulary } \\
\text { definitions } \\
\text { Teaching through verbal } \\
\text { explanation }\end{array}$ \\
\hline
\end{tabular}

So, the side gets longer as the angle gets bigger, and the angle gets bigger as the side gets longer. We are not saying that there is a proportion. We're just trying to say that if we reduce the measure of the angle, we reduce the length of side, if we reduce the side, we reduce the angle.

Openness

Interpersonal distance --- use of pronoun 'we' and related forms

Formalistic view of Teaching through verbal mathematics learning explanation

Mystery Wonder

Interpersonal distance- use of pronoun 'we' and related forms.

Interpersonal distance- use of 'student(s)' etc. greater than or equal to $\mathrm{B}$, the angle measure $\mathrm{B}$ is greater than or equal to $\mathrm{C}$, then order of the side lengths become as follows: length of side $a$ is greater than or equal to side $b$, length of side $b$ is greater than or equal to side $c$ and vice versa.

$(m(\hat{A}) \geq m(\hat{B}) \geq m(\hat{C}) \Leftrightarrow a \geq b \geq c)$
Formalistic view of Teaching through verbal mathematics learning explanation

\begin{tabular}{ll}
\hline Rationalism & Use of logical connectors \\
\hline Objectism & Symbolisation adopted
\end{tabular}

Sort the side lengths given in the figure from shorter to longer.

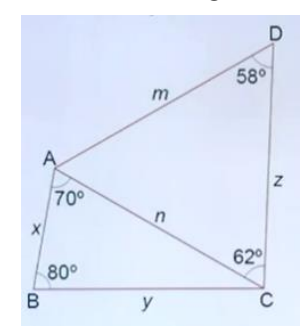

Facts \& theories

Context-free

The sum of the measures of the two internal angles is equal to the measure of the nonadjacent external angle, then the measure of this angle is $72^{\circ}$.

\begin{tabular}{ll}
$\begin{array}{l}\text { Instrumental } \\
\text { understanding }\end{array}$ & $\begin{array}{l}\text { Performance expectation- } \\
\text { knowing }\end{array}$ \\
\hline Rationalism & $\begin{array}{l}\text { Use of logical connectors } \\
\text { (then) }\end{array}$ \\
\hline
\end{tabular}


So, what do you see when you look at it? The largest of the red group is $\mathrm{n}$, and the smallest of the blue group is $n$. So, there is a sequence between these side lengths in the form of $\mathrm{x}<\mathrm{y}<\mathrm{n}<\mathrm{z}<\mathrm{m}$
Use of logical connectors

(So)

Objectism Symbolisation adopted

When Table 3 is examined, in the first example (friends, our subject is to show angle-side relationships in the triangle), the teacher conveys the openness value according to value indicators of Seah (1999). In the second example (A triangle has a longer side across a big angle and a small side across a small angle. If the measures of the angles are equal, then the opposite sides are equal), the teacher conveys the formalistic view of mathematics learning value (see Seah, 1999; Seah \& Bishop, 2000), because the teacher teaches new words and concepts through definitions. In another example, the mystery value (Let's see what we are facing) is conveyed according to Seah's (1999) value indicators. In the last example (So what do you see when you look at it? The largest of the red group is $n$, and the smallest of the blue group is $n$. So, there is a sequence between these side lengths in the form of $x<y<n<z<m$ ), the teacher conveys the inquiry value, rationalism by using a logical conjunction (see Bishop, 1988; Seah, 1999), and objectivity by expressing verbal expression symbolically (see Seah, 1999). In this way, the transcription of 14 lessons was examined in detail according to the value indicators.

As a result of the analysis, it was determined that objectism, openness, and rationalism in mathematical values are frequently espoused in the courses. If the mathematical values were analysed in pairs, it was determined that more emphasis is given to the openness of the openness-mystery value pair, and each of the value pair of objectism-rationalism was emphasised in a balanced way. Also, it was observed that there was not much emphasis on the control -progress value pair in the courses. On the other hand, in terms of mathematics educational values, it was determined that there was frequently emphasis on the values of formalistic view of mathematics learning, inquiry, instrumental understanding, facts \& theories. If the mathematics educational values were examined in pairs, it was determined that there was more emphasis on formalistic view of the mathematics learning-activist view of mathematics learning value pair and more emphasis was given to instrumental understanding of the instrumental understandingrelational understanding value pairs. In terms of fact $\&$ theories - ideas $\&$ practice value pairs, it was observed that there was more emphasis on facts $\&$ theories. It was determined that there was little emphasis on the ideas \&practice value. It was also observed that there was an emphasis on the inquiry value during the course. However, this emphasis on inquiry value remained only an attempt, as feedback was not received from students due to the asynchronous distance education. It was also determined that very little feedback was given after the attempt to transfer the inquiry value. Finally, it was also observed that there was more emphasis on the computation value of the application-computation value pair. 


\section{Discussion}

In this section, the results of the present study are discussed in terms of the mathematical and mathematics educational values of Grade 9 students in face-to-face education, the teachers who teach at this level and the values conveyed in the textbooks (values noted in the relevant literature and especially in the Turkey context). In this way, it will be revealed how much the values conveyed by distance education match or differ with the values transferred in face-to-face mathematics teaching. In this context, the discussion is presented under two subtitles as mathematical and mathematics educational values.

\section{Mathematical Values}

In the current study, it has been determined that there is balanced emphasis on objectism-rationalism mathematical value pair in the lessons. In addition, it was also determined that objectism value is usually transferred with symbolisation value signal and rationalism value is conveyed by using abstraction and logical connectors. In his study, Dede (2006), to determine the conveyed mathematical values in high school mathematics textbooks, has taken the logical connectors as a reference point for rationalism value, showing the action-reaction, cause and effect relationships in mathematical tasks. It was observed that there was more emphasis on openness value compared to its complementary, mystery value. It was observed that there was little emphasis on the control-progress values in the distance education process, and moreover, the control value was brought to the fore more in comparison to the progress value.

On the other hand, the study conducted to determine students' values in face-toface education revealed that Grade 9 students in Turkey gave more importance to objectism, openness, and progress values than complementary pairs (Dede, 2019). Accordingly, it is understood that the objectism and openness values conveyed in lessons through distance education coincide with the values conveyed to students by face-to-face education, and the rationalism value does not. However, Dede (2019) found in his international comparative study that Turkish, German, and Turkish immigrant students (Grade 9) living in Germany emphasised the value of rationalism. This reveals that teachers and students from different cultures show common approaches to the scientific discipline of mathematics (rationalism) in face-to-face education (see Atweh \& Seah, 2008; Zhang et al., 2016, for results of different cultures studies). Additionally, although there is less emphasis on progress in distance education courses, it is seen that students place more emphasis on progress in face-to-face classes. In fact, in his research to determine why mathematics is important, Dede (2012) found that Turkish and German mathematics teachers especially gave importance to rationalism and progress values in face-to-face education. Also, Dede (2012) found that rationalism, control, and openness values among mathematics values were emphasised more in textbooks. In their study, Aktaş and Argün (2018) concluded that high school mathematics teachers reflect the values of objectivism, control, and openness more in face-to-face teaching.

\section{Mathematics Educational Values}

In the current study, it has been determined that the values of formalistic view of mathematics learning, inquiry and instrumental understanding are frequently conveyed in the lessons. The fact that formalistic view of mathematics learning value is emphasised 
more than its complementary value pair in distance education courses can be considered an indication that teachers tend to teach the concept/subject more directly than the students discover in the distance education process. On the other hand, it is seen that instrumental understanding value is emphasised more than its complementary value pair. Here, it was observed that the teacher tended to convey the instrumental understanding value to the students by reminding them of his previous statements (e.g., firstly let's remember the definition of the triangle together). One reason why instrumental understanding is emphasised more in lessons in the current study may be due to the fact that the teacher emphasised too much on the value of formalistic view of mathematics learning. In addition, in the facts $\&$ theories-ideas \& practice value pairs, it was observed that the teacher predominantly reflects the value of facts $\&$ theories while teaching. In the lessons, transferring ideas \& practice values was very rare. However, in the study of Dede and Barkatsas (2019), it was determined that Grade 9 students place more emphasis on ideas \& practice value. This situation differs from the values emphasised by the students. If the process-product value pair is examined, it is seen that the teacher usually gives more importance to the process value.

Additionally, it was observed that the teacher also attaches importance to the inquiry value during the course, but the inquiry value remained only an attempt because the teacher could not receive feedback from the students due to the nature of the distance education. However, it was seen that the teacher did not give feedback after the attempt of the inquiry value. This may be because the teacher is aware that he is not interacting with the students, and therefore, he thinks that there is no need to give feedback. It was also observed that the computation value was transferred more from the applicationcomputation value pair in the courses. In addition, it is seen that the transfer of the feedback value is less in the courses. This differs from the results of the study of Dede and Barkatsas (2019) because, in the study of Dede and Barkatsas (2019), Grade 9 students emphasised the feedback value significantly. Feedback value is thought to remain only at the attempt level due to the limitation of distance education as in the inquiry value. To eliminate this negative situation, it is recommended that teaching with distance education should be made in an interactive manner with the support of technology. For example, the teacher can ask questions to students on a live broadcast and students can answer online. The teacher can see the students' answers on a live broadcast screen and coordinate the lesson accordingly. However, if this situation is considered in terms of process-- product value pairs, it can be said that this situation can bring the product value to the front.

\section{Limitations and Further Study}

In the current study, distance education was conducted across the country in the form of lectures taught by teachers at each grade level through a central system within the scope of EBA. Also, distance education courses are presented asynchronously. In this regard, these should be considered when interpreting the results of the current study. Therefore, the examination of values in mathematics (geometry) teaching with synchronous distance education can be suggested for further research. In addition, all the courses observed in this study were taught by a male teacher. Even though teachers prepare and get academic support before the lecture process, the gender, individual 
characteristics, and pedagogical approaches of this teacher may still have an impact on the results of this study. In this context, further research can be done through the course videos taken by teachers with different characteristics (gender, seniority, etc.). In addition, since the courses followed within the scope of this study are geometry-based (due to the mathematics curriculum of the Grade 9s during the time when the pandemic started and the distance education decision was made), the subject (geometry) may also have a possible impact on the results obtained in this study. Investigation of this situation (different mathematical topics and concepts, e.g., algebra) can also be suggested for further research. In addition, since there is no study in the literature about the values that students attach importance in the distance education process in previous studies, the discussions were made according to the values of the students, teachers in the face-toface teaching process, and mathematics textbooks. In this way, there has been a chance to reveal the possible similarities and differences of values conveyed by face-to-face and distance education. In this context, it is thought that the results of the present study will provide a sound basis for further studies to examine the values of students (and teachers) in the distance education process and will be useful in the better interpretation of the results of the present study.

\section{Statement of Responsibility}

Yüksel Dede, Veysel Akçakın and Gürcan Kaya conceived the idea and designed this study. All authors are responsible for writing and finalizing the paper. During the review process all authors revised the paper and approved the final version. 


\section{References}

Aktaş, F. N., \& Argün, Z. (2018). Examination of mathematical values in classroom practices: A case study of secondary mathematics teachers. Education and Science, 43(193), 121-141. http://dx.doi.org/10.15390/EB.2018.7177

Arber, S. (1993). Designing samples. In G. N. Gilbert (Ed.), Researching social life (pp. 68-92). Sage.

Atweh, B., \& Seah, W. T. (2008). Theorising values and their study in mathematics education. In P. L. Jeffery (Ed.), Proceedings of the 2007 AARE Conference. Association for Research in Education (AARE).

Bakker, A., \& Wagner, D. (2020). Pandemic: lessons for today and tomorrow? Educational Studies in Mathematics. https://doi.org/10.1007/s10649-020-09946-3

Barbera, E. (2012). Foreword. In A. Juan, M. Huertas, S. Trenholm, \& C. Steegmann (Eds.), Teaching mathematics online: Emergent technologies and methodologies (pp. viii-ix). Information Science Reference.

Bishop, A. J. (1988). Mathematical enculturation: A cultural perspective on mathematics education. Kluwer.

Bishop, A. J., FitzSimons, G., Seah, W. T., \& Clarkson, P. (1999, December). Values in mathematics education: Making values teaching explicit in the mathematics classroom. Combined Annual Meeting of the Australian Association for Research in Education and the New Zealand Association for Research in Education, Melbourne, Australia.

Cohen, L., Manion, L., \& Morrison, K. (2018). Research methods in education. Routledge.

Dede, Y. (2006). Mathematical values conveyed by high school mathematics textbooks. Educational Sciences: Theory \& Practice, 6(1), 118-132.

Dede, Y. (2012). Why is mathematics valuable?: A comparison of Turkish and German mathematics teachers. Mathematics Education Bulletin- BOLEMA, 26(44), 11711206. https://doi.org/10.1590/S0103-636X2012000400005

Dede, Y. (2015). Comparing primary and secondary mathematics teachers' preferences regarding values about mathematics teaching in Turkey and Germany. International Journal of Science and Mathematics Education, 13(1), 227-255. https://doi.org/10.1007/s10763-013-9483-z

Dede, Y. (2019). Why Mathematics Is Valuable for Turkish, Turkish Immigrant and German Students? A Cross-Cultural Study. In P. Clarkson, W. T. Seah, \& J. Pang (Eds.), Values and Valuing in Mathematics Education (pp. 143-156). Springer.

Dede, Y., \& Barkatsas, T. (2019). Developing a questionnaire to evaluate Turkish students' mathematics values and preferences. Journal of Theoretical Educational Science, 12(4), 1142-1163. http://dx.doi.org/10.30831/akukeg.529092

Diestler, S. (2012). Becoming a critical thinker: A user-friendly manual. Pearson.

Haylock, D., \& Thangata, F. (2007). Key concepts in teaching primary mathematics. Sage.

Hill, B. V. (1991). Values education in Australian schools. Australian Council for Educational Research. 
Juan, A., Huertas, M., Trenholm, S., \& Steegmann, C. (2012). Preface. In A. Juan, M. Huertas, S. Trenholm, \& C. Steegmann (Eds.), Teaching mathematics online: Emergent technologies and methodologies (pp. X-xiii). Information Science Reference.

Landis, J. R., \& Koch, G. G. (1977). The measurement of observer agreement for categorical data. Biometrics, 159-174.

Lim, C. S., \& Ernest, P. (1997, March and June). Values in mathematics education: what is planned and what is espoused? British Society for Research into Learning Mathematics day conferences, Nottingham, England.

Lin, F.-C., Wang, C.-Y., Chin, C., \& Chang, G.-Y. (2006). Why student teachers teach or do not teach the professed values. In J. Novotna, H. Moraova, M. Kratka, \& N. Stehlikova (Eds.), Proceedings of the 30th Conference of the International Group for the Psychology of Mathematics Education (Vol. 4, pp. 81-88). Charles University.

Lincoln, Y. S., \& Guba, E. G. (1985). Naturalistic inquiry. Sage.

MacNealy, M. S. (1999). Strategies for empirical research in writing. Longman.

Ministry of National Education (MEB). (n.d.). Firsatlarl Artırma ve Teknolojiyi Iyileştirme Hareketi [Movement of Enhancing Opportunities and Improving Technology]. Milli Eğitim Bakanlığı. Retrieved 02.04.2020 from http://fatihprojesi.meb.gov.tr/about.html

Moore, M. G. (2019). The theory of transactional distance. In M. G. Moore \& W. C. Diehl (Eds.), The handbook of distance education (pp. 32-46). Routledge.

National Council of Supervisors of Mathematics (NCSM) and the National Council of Teachers of Mathematics (NCTM). (2020). Moving Forward: Mathematics Learning in the Era of COVID-19. https://www.mathedleadership.org/docs/resources/NCTM_NCSM_Moving_Forwar d.pdf

Organisation for Economic Co-operation and Development [OECD]. (2019a). OECD Future of education and skills 2030: Conceptual learning framework. Attitudes and values. $\quad \mathrm{http}: / / w w w . o e c d . o r g / e d u c a t i o n / 2030$-project/teaching-andlearning/learning/attitudes-andvalues/Attitudes_and_Values_for_2030_concept_note.pdf

Organisation for Economic Co-operation and Development [OECD]. (2019b). OECD Future of education and skills 2030: What is the Learning Compass? http://www.oecd.org/education/2030-project/teaching-and-learning/learning

Organisation for Economic Co-operation and Development [OECD]. (2019c). An OECD Learning Framework 2030. In C. Bast \& D. F. J. Campbell (Eds.), The Future of Education and Labor (pp. 23-35). Springer.

Organisation for Economic Co-operation and Development [OECD]. (2019d). PISA 2018 Results (Volume I): What Students Know and Can Do (Vol. I). Author. https://doi.org/http://dx.doi.org/10.1787/9789264266490-en

Powe, K. W. (1993). Values education and the local school board. Updating School Board Policies, 24(6), 1-4. 
Seah, W. T. (1999). The portrayal and relative emphasis of mathematical and mathematics educational values in Victoria and Singapore lower secondary mathematics textbooks: A preliminary study Monash University]. Melbourne, Australia.

Seah, W. T. (2003, November-December). The professional socialisation of teachers in transition: A values perspective. International Education Research Conference AARE-NZARE, Auckland, New Zealand.

Seah, W. T. (2008). Valuing values in mathematics education. In P. Clarkson \& N. Presmeg (Eds.), Critical issues in mathematics education: Major contributions of Alan Bishop (pp. 239-252). Springer.

Seah, W. T. (2011). Study 3 What I find important (in maths learning): Discussion paper [Unpublished manuscript].

Seah, W. T., \& Andersson, A. (2015). Valuing diversity in mathematics pedagogy through the volitional nature and alignment of values. In A. J. Bishop, H. Tan, \& T. N. Barkatsas (Eds.), Diversity in mathematics education (pp. 167-183). Springer.

Seah, W. T., Baba, T., \& Zhang, Q. (2017). The WIFI study: Students' valuing of mathematics learning in Hong Kong and Japan. In J.-W. Son, T. Watanabe, \& J.-J. Lo (Eds.), What Matters? Research Trends in International Comparative Studies in Mathematics Education (pp. 333-354). Springer.

Seah, W. T., \& Bishop, A. J. (2000, April). Values in mathematics textbooks: A view through two Australasian regions. Annual Meeting of the American Educational Research Association, New Orleans, LA.

Tavşanc1l, E., \& Aslan, A. E. (2001). Sözel, yazılı ve diğer materyaller için içerik analizi ve uygulama örnekleri[Content analysis and application examples for oral, written and other materials]. Epsilon.

Taylor, R. L. (2015). Community college perceptions of online education. A review of the literature. In A. G. Scheg (Ed.), Critical examinations of distance education transformation across disciplines (pp. 237-259). Information Science Reference.

White, L. A. (1959/2007). The evolution of culture: The development of civilization to the fall of Rome. Left Coast. Table of contents only http://www.loc.gov/catdir/toc/ecip078/2007000279.html

Yıldırım, A., \& Şimşek, H. (2008). Sosyal bilimlerde nitel araştırma yöntemleri [Qualitative research methods in social sciences]. Seçkin.

Zhang, Q., Barkatsas, T., Law, H.-Y., Leu, Y.-C., Seah, W. T., \& Wong, N.-Y. (2016). What primary students in the Chinese Mainland, Hong Kong and Taiwan value in mathematics learning: A comparative analysis. International Journal of Science and Mathematics Education, 14(5), 907-924. http://dx.doi.org/10.1007/s10763-0149615-0 